\title{
イオンビームによるステンレス鋼ナイフェッジの バリ取りと形状制御*
}

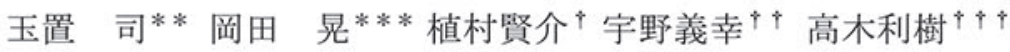

Study on Deburring and Shape Control of Stainless Steel Knife Edge by Ion Beam Machining

Tsukasa TAMAOKI, Akira OKADA, Kensuke UEMURA, Yoshiyuki UNO and Toshiki TAKAGI

\begin{abstract}
Forming the cutting edge of stainless steel cutlery is generally carried out by grinding wheel and polishing with leather strop. Nanometer-level shape controllability of the edge in the polishing process is strongly required for better cutting performance. In order to achieve stably high shape accuracy of cutting edge, high technical skill has been needed, considering the wear of lather strop and the changes in environmental conditions, such as temperature and humidity. In this study, deburring and shape control of cutting edge by ion beam machining were experimentally investigated as an alternative to the conventional leather strop polishing. Experimental results clarified that ion beam irradiation from the front to the edge made the edge shape dull, while that from the side made it sharp. By continuously changing the direction of ion beam irradiation to the edge, the burr was perfectly removed and the edge radius in several $\mathrm{nm}$ was successfully obtained. Furthermore, the cutting performance was highly improved by plasma nitriding after the edge finishing with the multi-directional ion beam irradiation, compared with that of conventionally finished one with leather strop.
\end{abstract}

Key words : ion beam, stainless steel cutlery, edge shape, multi-directional, cutting performance

\section{1. 緒言}

ステンレス製刃物の刃先は, マルテンサイト系ステンレス材 料の薄板に焼き入れ, 焼き戻し処理を施し, さらに砥石研削を

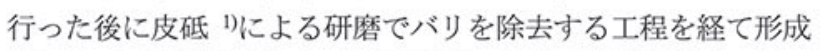
される. 図 1 (a)に示した皮砥研磨前の刃先 SEM 写真は, 砥石 研削によって大まかな刃先が形成されていることがわかるが, 最先端にはバリが残っているため, 例えばカミンリでは髭を剃 ることができない.一方, 図 1(b) は, 皮砥研磨によって刃先の バリが完全に除去され，滑らかに仕上がっていることがわかる. このような研磨加工はカミソリのみならず, カッターナイフや 包丁などでも行われており, 十数年前には理䯲店でも皮で刃先 を研ぐ光景を目にすることができた. また, 刃の種類は切断対 象物によって様々なサイズや刃先厚み形状が存在し, 中でも精 密な切断を要する刃については, 切れ刃の鋭利さにおいてナ, メートルオーダでの形状精度が求められているため, 研磨によ るバリ除去と同時に刃先形状を制御する必要がある. 従来の皮 砥研磨等, 機械加工で高精度な刃先形状を安定的に形成するに は, 皮砥自身の摩耗による形状変化や, 研磨時の気温・湿度等 を考虑した取り扱いが必要である. よって安定した品質の刃先 を作るには長年の経験的技能が必要とされる. また, 皮砥は職 人が 1 枚 1 枚手作りで製作しているため, 製品毎に特性が異な ることや, 後継者不足により安定的供給ができなくなる可能性 が桬念されている.

近年, 機械加工による研磨に代わるエッチング技術が発達し たことで, 電子デバイスやマイクロマシンを対象とした微細加

\footnotetext{
・原稿受付 平成 26 年 11 月 5 日 揭載決定 平成 27 年 1 月 19 日

* 正会員 カイインダストリーズ條（岐阜県関市小屋名 1110)

… 正会員 岡山大学大学院 (岡山県岡山市北区津島中 3-1-1)

†アイタック㑣（兵庫県宝塚市新明和町 1 番 1 号)

中+ 中国職業能力開発大学校 (岡山県倉敷市玉島長尾 1242-1)

†† カイインダストリーズ寈（岐阜県関市小屋名 1110)
}

工技術が急速に成長している. 中でもプラズマエッチングは22)3), 半導体製造プロセスに欠かせない存在となっている. 著者らは, これまでプラズマ窒化による刃先の高硬度化を達成しており ${ }^{4)}$, プラズマプロセスでは微細な加工もできることから, より効率 が高く異方性を有するイオンビームエッチング5)のよって刃先 のバリ取りと高精度な形状加工が可能になるのではないかと考 えられる. そこで本研究ではイオンビームによる刃先のバリ取 りと刃先形状変化について実験的に考察し, 高精度な刃先形成 の可能性を検討した.

\section{2. 装 置 概 要}

図 2 に本研究で使用したイオンビーム加工装置 7)を模式的に 示す. 装置は真空チャンバ, 真空ポンプ, イオンビームガンで 構成されている. イオンビームガン内部に導入されたアルゴン ガスは, $2.0 \mathrm{~mm}$ 幅のスリットからイオン加速電圧の印加によっ てプラズマ状態で照射される. 放出されたイオンは, スリット から $90 \mathrm{~mm}$ 離れた位置に設置された試料表面で $60 \mathrm{~mm}$ 幅に拡散 され, 試料に衝突することで刃先の加工を行う.

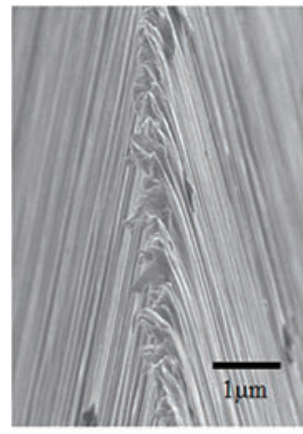

(a) Before polishing

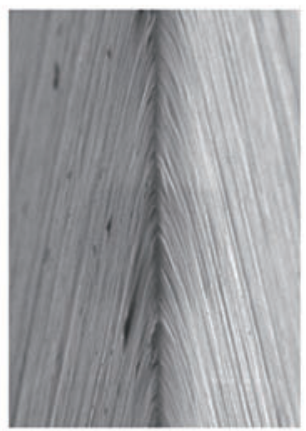

(b) After polishing
Fig.1 SEM images of blade edge before and after polishing with leather strop 


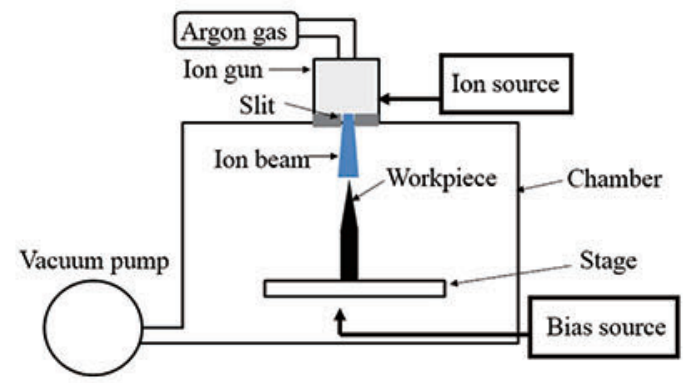

Fig.2 Ion beam machining equipment

\section{3. 評 価 結 果}

\section{1 イオンビームエッチング加エ特性}

イオンビームエッチングによるカミソリ刃のバリ取りと形状 制御について検討するに当たり, はじめに処理時間とイオンガ ンの加速電圧值がエッチングレートに及ぼす影響を調査した. エッチング量の測定は, 試料表面の一部を水糊でマスキングし, 加工面と未加工面の段差を AFM にて測定した. 加工条件を表 1 に示す. 電圧を $2 \sim 4 \mathrm{kV}$, 処理時間を $60 \sim 180$ 分と変化させ, 試 料は鏡面 $(\mathrm{Ra}=0.02 \mu \mathrm{m})$ に仕上げた SUS420J2 を使用した.

イオンガンの電圧を $3 \mathrm{kV}$ で一定とし，加工時間を $60 \sim 180$ 分 に変化させた場合のエッチング量の測定結果を図 3 (a) に示す. エッチング量と加工時間はほぼ比例の関係にあり, 処理時間が 長くなるほどェッチング量は直線的に増加している. エッチン グレートは約 $0.2 \mu \mathrm{m} / \mathrm{h}$ となっている. 次に加工時間を 180 分で一 定とし, 電圧を $2 \mathrm{kV} \sim 4 \mathrm{kV}$ に変化させた場合のエッチング量測 定結果を図 3(b) に示す. 電圧によるエッチング量もほぼ比例の 関係になっており, 電圧が増加するにつれエッチング量も増え ていることがわかる. エッチングレートは $2 \mathrm{kV}$ で約 $0.1 \mu \mathrm{m} / \mathrm{h}, 3 \mathrm{kV}$ で約 $0.2 \mu \mathrm{m} / \mathrm{h}, 4 \mathrm{kV}$ で約 $0.3 \mu \mathrm{m} / \mathrm{h}$ となっている.

\section{2 イオンビームによる刃先のバリ取りと形状制御}

3.2 .1 照射角度と刃先形状の関係

本節では, イオンガンの加速電圧を変化させた場合にカミソ リ刃先のバリがどのように除去されるかを観察した. 加工条件 を表 2 に示す. 試料は一般的なカミソリ材料である SUS420J2 相当材（日立金属社製銀紙 5 号）を使用し，熱処理と砥石によ る研削工程を経て刃先を形成し, 刃先は 20 度の角度で成形され ている. 次に刃先に対するビーム照射角度を変化させることで バリの状態と刃先形状の変化を評価した. 図 4 (a) にイオンビー 么照射方向と刃先の位置関係を示寸. ビーム照射角度 $\theta=0^{\circ}$ の場 合は, 刃先に対して真上から 180 分間イオンビームが照射され る. 図 4 (b) に示すような $\theta= \pm 45^{\circ}$ おび $\pm 90^{\circ}$ の場合, 片側から 90 分照射した後に反対側からも 90 分, 合計で 180 分間照射を行う. さらに, 図 4 (c)に示すような連続的にビームを照射しながら $\theta$ を $0^{\circ} \pm 90^{\circ}$ と変化させる方法も試みた。

イオンガンの加速電圧を $2 \sim 4 \mathrm{kV}$ 変化させた場合, バリの除 去具合と刃先形状がどのように変化するか確認した. イオンビ ームを刃先正面 $\left(\theta=0^{\circ}\right)$ から照射した場合の, SEMによる観察 結果を図5に示す. 钼察結果より, $2 \mathrm{kV}$ では刃先にバリが残って おり, 刃先が右側に倒れ込んでいる様子を確認できる. 電圧を $3 \mathrm{kV}, 4 \mathrm{kV}$ と増加させるにつれ, 刃先は大きくエッチングされ, バリが除去されている様子が確昭できる. しかし，4kVの条件で はバリが除去される以上にエッチングが進み, イオンビーム照 射前より鈍角に形成されていることがわかる. 刃先角度はSEM
Table 1 Test conditions of ion beam etching for test pieces

\begin{tabular}{c|c}
\hline Process pressure P Pa & 0.1 \\
\hline Ion source voltage V kV & $2,3,4$ \\
\hline Ion current I A & 0.4 \\
\hline Distance from ion gun to workpiece L mm & 90 \\
\hline Process time t min. & $60,120,180$ \\
\hline Process gas & Argon \\
\hline
\end{tabular}

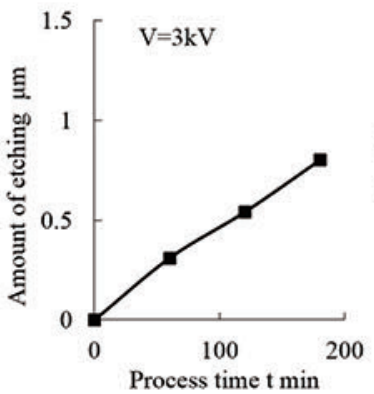

(a) Process time

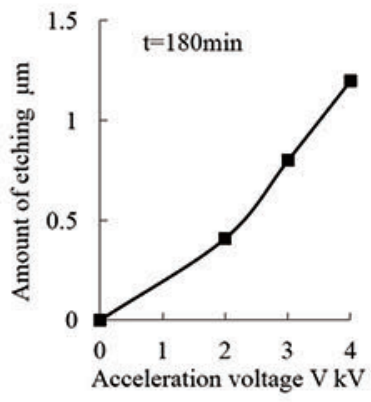

(b) Acceleration voltage
Fig.3 Variation of etching amount with process condition

Table 2 Ion beam etching conditions for razor blades

\begin{tabular}{c|c}
\hline Process pressure P Pa & 0.1 \\
\hline Ion source voltage V kV & 3 \\
\hline Ion current I A & 0.4 \\
\hline Distance from ion gun to workpiece L mm & 90 \\
\hline Process time $\mathrm{t} \mathrm{min.}$ & 180 \\
\hline Ion beam angle $\theta$ degree & $\begin{array}{c}0, \pm 45, \pm 90, \\
\text { Multi-directional }\end{array}$ \\
\hline Process gas & Argon \\
\hline
\end{tabular}

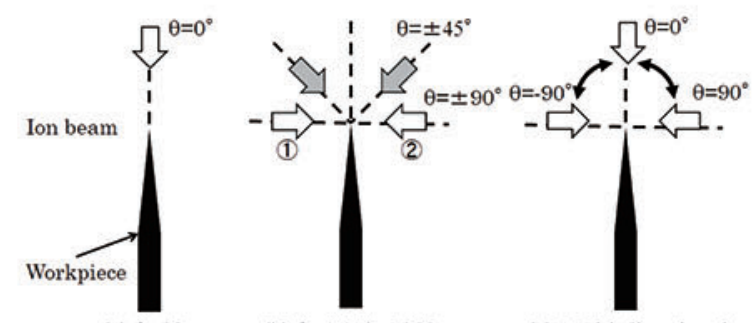

(a) $\theta=0^{\circ}$

(b) $\theta= \pm 45^{\circ}, \pm 90^{\circ}$

Fig.4 Ion beam irradiating method

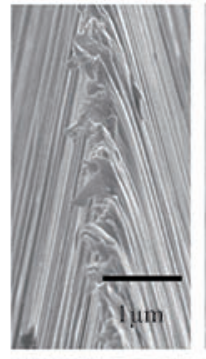

(a) Before etching

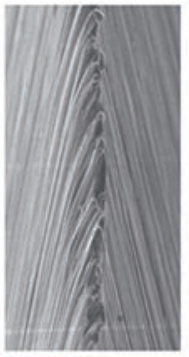

(b) $\mathrm{V}=2 \mathrm{kV}$

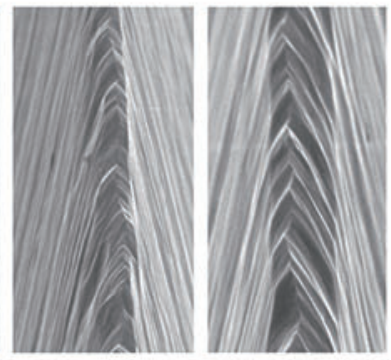

(c) $\mathrm{V}=3 \mathrm{kV}$ (d) $\mathrm{V}=4 \mathrm{kV}$
Fig.5 Variation of etching amount with acceleration voltages $\left(\theta=0^{\circ}\right)$

画像解析ソフト “Scandium” にて測定すると約70 8 $80^{\circ}$ になって いる. これは, イオンビーム入射角によるエッチングレートの 違い8), 寸なわちビーム照射角度が 50 前後の場合に, エッチン グレートが最大となる現象に起因していると考えられる. その 角度依存性により結果として $80^{\circ}$ の刃先形状が形成されたと考 えられる. 


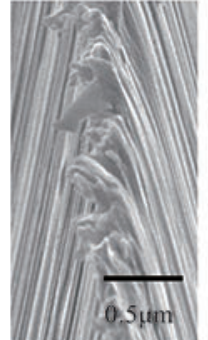

(a) Before etching

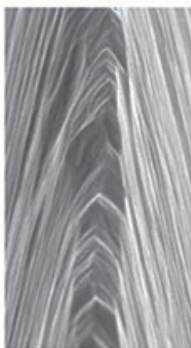

(b) $\theta=0^{\circ}$

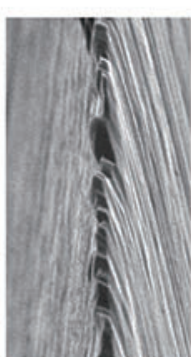

(c) $\theta=45^{\circ}$

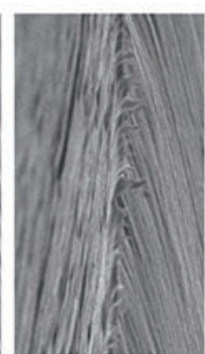

(d) $\theta=90^{\circ}$

Fig.6 SEM images of blade edge with various ion beam angles

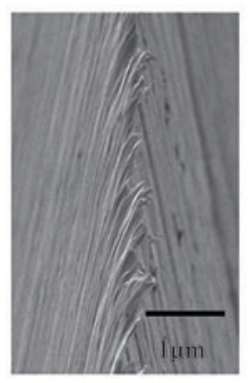

(a) Before etching

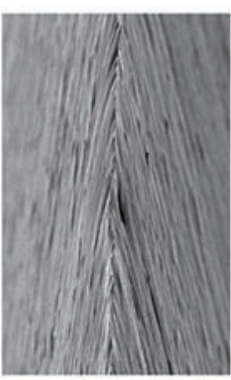

(b) $\mathrm{t}=120 \mathrm{~min}$.

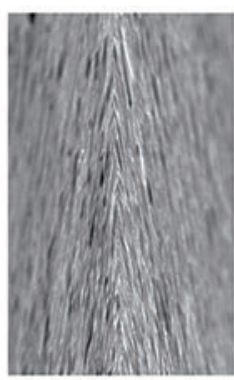

(c) $\mathrm{t}=180 \mathrm{~min}$

Fig.7 SEM images of blade edge with multi-directional ion beam irradiation for various process times

次に, ビームの照射角度が刃先形状一及ぼす影響を検討した. その結果を図6に示寸. 図より，照射角0○すなわちイオンビーム を刃先から鉛直下向きに照射した場合では, バリの除去はでき ているが，最先端が鈍角に形成される．また，照射角 $45^{\circ} て ゙$ 加工 した場合は, 刃先形状はあまり変化しておらず，鋭角が保たれ ている. しかしながら, 刃先のバリは完全に除去されていない ことが確認できる. さらに, 照射角90で加工した場合も照射角 $45^{\circ}$ と同様, 刃先形状の変化は少ないが, バリは完全に除去され ない結果となった. 側面からの照射により, ビームはエッチン グレートの小さい照射角となり, 刃先のバリ除去効率が低下し たと考えられる.

$\theta=0^{\circ}$ 条件では, バリの除去はできるものの刃先が鈍角にな

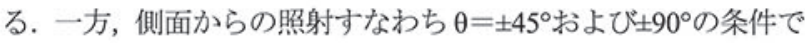
は形状の変化は少なく刃先は鋭角に保たれるが, バリが除去で きない結果となった. そこで, 刃先の鈍角化を抑えつつバリの 除去を行うことができる方法として, イオンビーム照射角を $0^{\circ}$ から $90^{\circ}$ の角度で連続的に変化させ, 正面と側面の照射を同時 に行う実験を行った. これを多方向照射(Multi-directional)と呼ぶ. この実験で照射角度を $0^{\circ} \Rightarrow 90^{\circ} \Rightarrow 0^{\circ} \Rightarrow-90^{\circ} \Rightarrow 0^{\circ}$ と変化さ せ, 1 周期は 20 秒に設定した. エッチング前と多方向照射で 120 分および 180 分の処理時間で加工した刃先 SEM 写真を図 7 に示 寸. 図 7(b)の 120 分の処理では, バリの除去が十分出来ている ことが確認することができる. 刃先先端を SEM にて 10 万倍で 拡大撮影し, 3.2.1 で使用した画像解析ソフトで先端半径 R を計 測した結果 3 5nm となり，従来の皮砥加工で作製することは不 可能な, 小さな先端半径の切れ刃を形成することができた． 一 方, 図 7(c)に示寸処理時間 180 分の刃先は, 120 分の処理と比へ バリの除去具合や先端半径の仕上がりに大きな変化は見られな いが, 表面が荒れていることがわかった.

次に, 刃先の形状変化を定量的に測定した. 測定には3.2.1 で 使用した画像解析ソフトを用いた. 測定結果を図 8 に示す. 横 軸に刃先最先端からの距離, 縦軸にその距離での刃の厚みを示 す. 図より皮砥で研磨した刃先は加工前よりも研磨により刃先

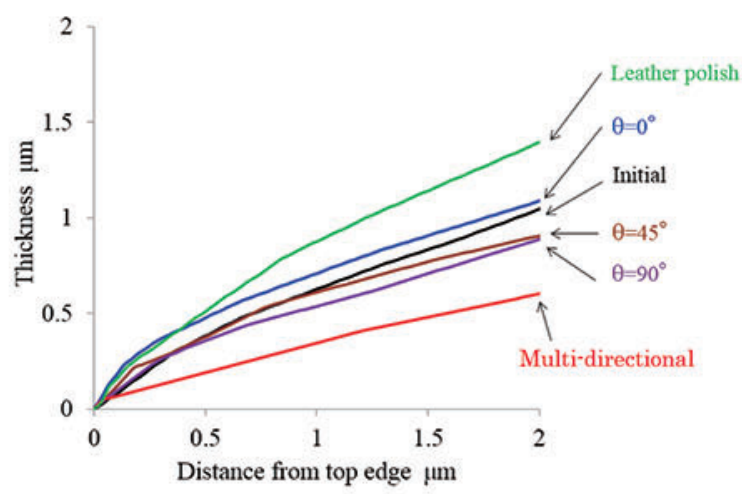

Fig.8 Variations of thickness with distance from the edge for various ion beam angles
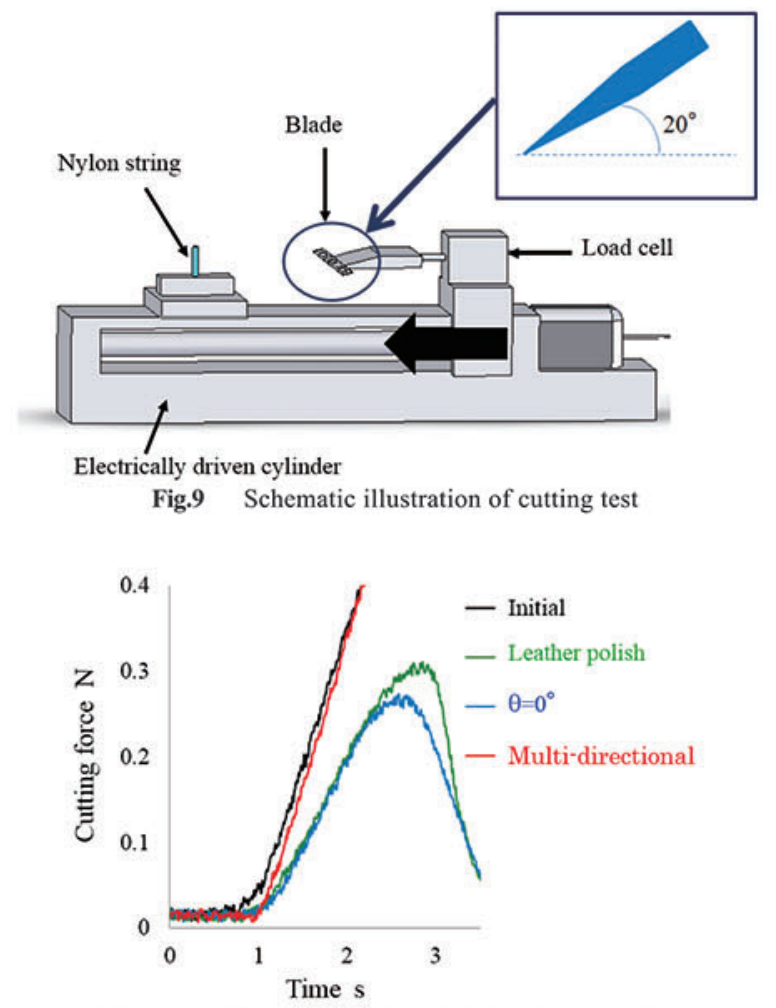

Fig.10 Cutting test result compared ion beam etching

が丸くなり, 厚み形状が増加している. また, イオンビーム照 射角 $0^{\circ}$ の場合の刃先はイオンビーム照射前より鈍角に形成され たため, 最先端のみ厚み形状が大きくなっている. さらに, 照 射角 $\pm 45^{\circ}, \pm 90^{\circ}$ の条件において刃先形状は照射前とほぼ同等に なった. これらに対し, 多方向照射は照射前の刃よりも厚みが 薄く, 刃先角度が小さくなっている.

\subsection{2 切断性能評価}

本実験で処理をした試料を用いて, 切断性能の評価を行った. 切断性能評価装置を図9に示寸. 装置は試料刃物, 電動シリンダ, 切断荷重測定用ロードセルで構成され，20度の角度で取り付け られた刃が, 電動シリンダによって0.025 $\mathrm{mm} / \mathrm{s} の$ 速度でナイロン テグスを切断し，切断時の荷重をロードセルにて計測した．ま た,ナイロンテグスの直径は $0.1 \mathrm{~mm}$ で保持部からの突き出し量は $5 \mathrm{~mm}$ となっている. 測定結果を図10に示寸. 図より，照射前の 刃は, 刃先にバリが大きく残っているためテグスの切断ができ ず，切断荷重が高くなっている. これに対し，従来の皮砥研磨 で加工した刃では, 刃先にバリがないためテグスを切断する 


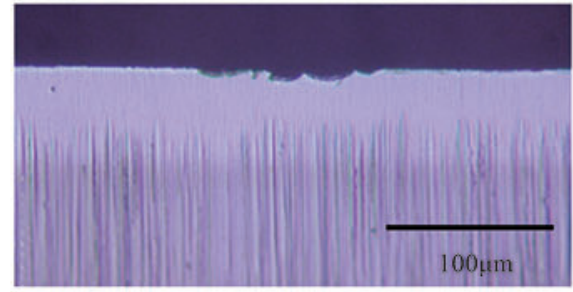

Fig.11 Photograph of cutting edge etched by multi-directional ion beam irradiation after cutting nylon string

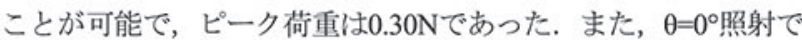

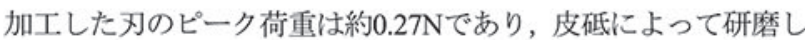
た試料よりも低い荷重でテグスを切断できた．これは，最先端 は釱角になったが，前述した通り皮砥研磨した刃よりも刃先形 状が薄いため，切断抵抗が低くなったと考えられる，一方，多 方向照射で加工した刃は，最も刃先角度が小さいにもかかわら ず全くテグスが切断できない結果となった. この原因を確認す るため, 切断後の刃先を顕微鏡にて観察した. 刃先写真を図11 に示す. テグスの直径に当たる, 約 $100 \mu \mathrm{m} の$ 幅にわたって変形し ており，刃先角度が小さすぎたことで刃先強度がテグスよりも 低かったために，切断できなかったと考えられる.

\section{3 イオンビームとプラズマ窒化処理による刃物の性能向上}

3.3.1 加工条件と刃先形状の関係

多方向照射を行うことで, 従来の加工方法では形成が不可能 なレベルで, 切れ刃先端半径の先鋭化ならびに刃先角度の鋭角 化に成功した. しかしながら刃先の厚み形状が薄すぎることで, 切断性能評価において刃先が破損してしまう結果となった。 そ こで, イオンビームエッチングの多方向照射(Multi-IB)によって 刃先角度が小さくなった刃先に, プラズマ窒化処理(Plasma nitriding : PN)を施すことで硬度を上昇させ, 切断性能と耐久性を 兼ね備えた刃先を形成できるのではないかと考え, 実験および 評価を行った。

実験には図 2 で示したイオンビームエッチング装置を用い, その後プラズマ窒化処理を施した. 試料は3.1.2 で使用したカミ ソリ材にプレス，熱処理の後に砥石による刃付けを行い，仕上 げの皮砥研磨は行っていないものを用いた. 試料の加工工程を 図 12 に示す. 実験の工程として, はじめにイオンビームエッチ ングを多方向照射で 120 分加工し, 次にプラズマ窒化を 120 分 と 180 分施し, 刃先を硬化させることで耐久性を付与した.

実験で作製した刃先写真を図 13 に示寸. 図 13(a)は多方向照 射によるイオンビームエッチング(Multi-IB)を 120 分処理したも の, 図 13(b)は多方向照射イオンビームエッチング後に 120 分ブ ラズマ窒化を行い，図13(c)は同じくエッチング後に 180 分プラ ズマ窒化を行ったものである. 写真より, 多方向照射イオンビ ームエッチングのみで処理した刃先と比べ, プラズマ窒化を加 えたものは，窒化処理時のエッチング効果によって刃先がわず かに鈍角になっていることがわかるが，これはプラズマ窒化処 理のみを刃先に施した際の結果とほぼ一致する ${ }^{9}$. 次に, 刃先形 状の測定結果を図 14 に示す．図より，イオンビーム多方向照射 とプラズマ窒化で作製した試料は，最先端が鈍角に形成された 分厚み形状が増加していることを定量的に確認できる. また, 厚み形状の増加は窒化処理時間に比例し, 180 分の処理で未処理 の刃とほぼ同等になっている. 未処理の刃は，バリがあるため 刃物としては使用できず, 皮砥研磨後の刃では厚み形状が大き

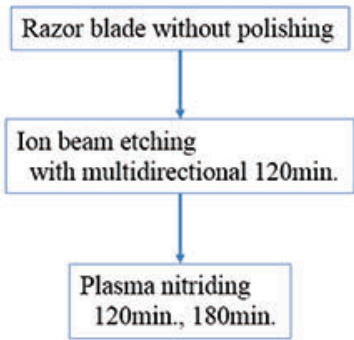

Fig.12 Procedure of ion beam etching and plasma nitriding process

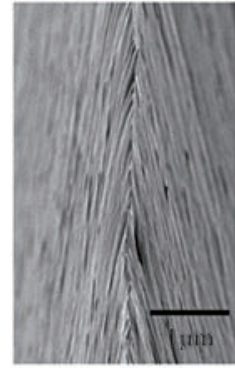

(a) Multi-IB $120 \mathrm{~min}$

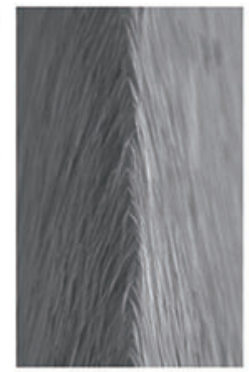

(b) Multi-IB $120 \mathrm{~min}$ + PN $120 \mathrm{~min}$

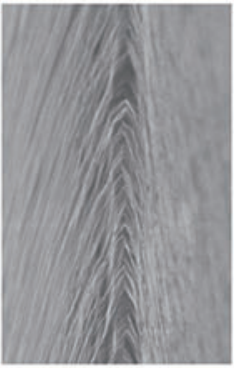

(c) Multi-IB $120 \mathrm{~min}$ + PN $180 \mathrm{~min}$.
Fig.13 SEM images of blade edge processed with various plasma treatment combinations

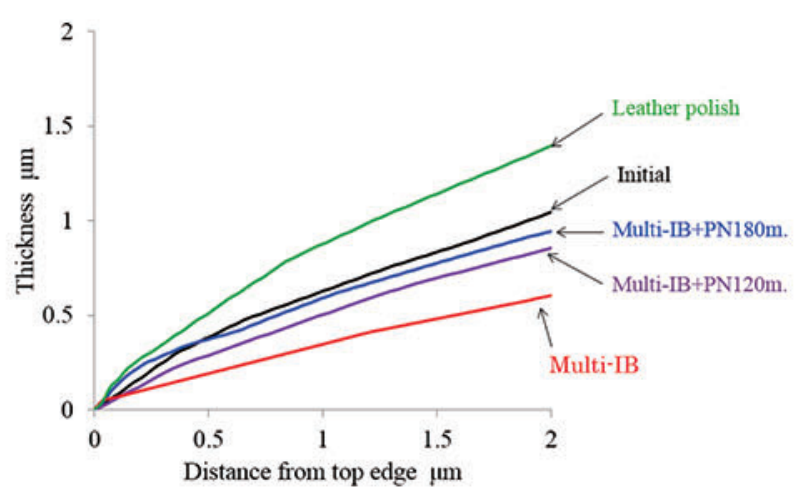

Fig.14 Variations of thickness with distance from the edge for various plasma treatment combinations

く増加している. よって, 今回の実験で作製した多方向照射+プ ラズマ窒化 120 分の試料は, 多方向照射のみの試料よりも形状 は厚くなったが，従来の皮砥による仕上げよりは形状を薄く仕 上げることが可能となった。

\subsection{2 切断性能評価}

イオンピームエッチングとプラズマ窒化によって作製した試 料で, テグス切断による切断性能評価を実施した. 結果を図 15 に示寸，多方向照射によるエッチングのみで作製した試料は, 3.2 で示したようにテグスを切断する強度が十分でない, 一方, 多方向照射とプラズマ窒化で作製した試料は $0.24 \mathrm{~N}$ と従来の皮 砥研磨による刃先よりも低い切断荷重を示した．また，プラズ マ窒化の処理時間 120 分と 180 分のものを比較すると, わずか に 120 分処理の切断荷重が低い結果となった. 以上より, 多方 向照射によって刃先角度が小さくなった反面, テグスの切断に 耐える強度がなくなった刃先に対してプラズマ窒化処理を施す ことで, 若干刃先の厚みは増加したもののテグス切断に耐えう る強度を付与し, 従来の皮砥研磨で仕上げた刃先よりも約 $20 \%$ 切断性能が向上したことが明らかとなった。 


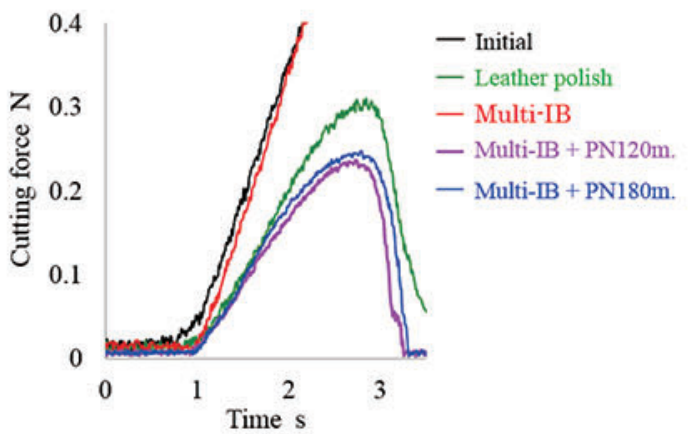

Fig.15 Cutting test result for various plasma treatment combination

\subsection{3 剃り味評価試験}

カミソリの切れ味を評価するうえで, 剃り味試験は重要な評 価方法の 1 つであるが, 官能評価が故にその手法については確 立されておらず, カミソリメーカー各社のノウハウとなってい るのが現状である. ただし, 剃り味試験は顧客の評価に最も近 い評価方法であり, 製品仕様を決定する際には必ず実施されて いる. そこで, 今回作製したサンプルを用い, 銺剃りとしての 性能を比較した. 剃り味試験の流れは下記の通りである.

(1)サンプルの準備と評価者の選定

今回の剃り味評価試験では, 剃り味のサンプルとして皮砥研 磨で仕上げた刃（サンプル A） と, 皮砥研磨なしで, 多方向照 射によるイオンビームエッチングの後にプラズマ窒化処理 120 分を行った刃 (サンプルB) に対し, チタン合金皮膜と PTFE 成 膜を施した 5 枚刃カミソリを評価者一配布した. 評価者は年齢 20 代から 50 代まで各 5 9 名ずつ, 合計 30 名を選定した.

(2)評価およびアンケート用紙の記入

サンプルを配布された評価者は, 1 日 1 回の髦剃りを 5 日間に 渡って, 都度 2 種類のサンプルで左右片側ずつ砦を剃り, アン ケート用紙に沿って点数評価を行う. アンケートの内容は, 抵 抗なくスムーズに剃れたか, 深剃り具合はどうであったか, 使 用後の肌の状態はどうであったかという項目に対して評定尺度 法を用いた. アンケートで用いた質問事項に対する尺度を表 3 に示す. 被験者は質問に対して 1 5 点の点数をつけ, 満足度が 高いほど高得点とする.

\section{(3)集計およびデータ解析}

集計ではそれぞれの評価項目と使用回数に応じて平均点を算 出し, 点数の高い方が切れ味のよいカミソリとして判断する.

評価結果を表 4 に示す. 結果より, 平均点ではスムーズさと 剃った後の肌の状態についてはサンプル B の方が平均点は高か った. これは, 訾を剃る際の切断抵抗が低くなったことでスム ーズにカミソリをストロークすることができたと考えられる. また, 眦剃り後の肌の状態も, A と比較して快適に感じる結果 となった.

一方, 深剃りの項目ではサンプル A の方が平均点は高い結果 となった. これは, サンプル A はヒグを切る際の切断抵抗が高 いため皮膚に不快感を伴う反面, 切断時に鬔が引つ張り出され たことで，より毛根に近い部分の髮をカットできたのではない かと考えられる.

\section{4. 結言}

イオンビームエッチングによるステンレス刃物のバリ取りと 形状制御について研究を行った結果, 以下の結㖮を得た.

(1) イオンビームを刃先正面から照射すると, 処理時間 180 分,
Table 3 Shaving test results

\begin{tabular}{c|l|l|l}
\hline Score & \multicolumn{1}{|c}{$\begin{array}{c}\text { Smoothly of } \\
\text { shave }\end{array}$} & \multicolumn{1}{|c}{$\begin{array}{c}\text { Closeness of } \\
\text { shave }\end{array}$} & \multicolumn{1}{|c}{ Skin condition } \\
\hline 5 & Very smooth & Very close & Very comfortable \\
\hline 4 & Smooth & Close & Comfortable \\
\hline 3 & Neither of them & Neither of them & Neither of them \\
\hline 2 & Not smooth & Not close & Uncomfortable \\
\hline 1 & Not smooth enough & Not close enough & Very uncomfortable \\
\hline
\end{tabular}

Table 4 Shaving test results

\begin{tabular}{|c|c|c|c|c|}
\hline \multirow{2}{*}{$\begin{array}{c}\text { Evaluation } \\
\text { points }\end{array}$} & \multirow{2}{*}{$\begin{array}{c}\text { Test } \\
\text { number }\end{array}$} & \multicolumn{2}{|c|}{ Score } & \multirow{2}{*}{$\begin{array}{r}\text { Subtract } \\
\text { B-A }\end{array}$} \\
\hline & & $\begin{array}{c}\text { Sample } \\
\text { A }\end{array}$ & $\begin{array}{c}\text { Sample } \\
\text { B }\end{array}$ & \\
\hline \multirow{5}{*}{$\begin{array}{l}\text { Smoothly of } \\
\text { shave }\end{array}$} & 1 & 3.71 & 3.83 & 0.13 \\
\hline & 2 & 3.75 & 3.83 & 0.08 \\
\hline & 3 & 3.73 & 3.82 & 0.09 \\
\hline & 4 & 3.55 & 3.85 & 0.30 \\
\hline & 5 & 3.50 & 3.70 & 0.20 \\
\hline \multirow{5}{*}{$\begin{array}{l}\text { Closeness of } \\
\text { shave }\end{array}$} & 1 & 3.67 & 3.50 & -0.17 \\
\hline & 2 & 3.75 & 3.67 & -0.08 \\
\hline & 3 & 3.73 & 3.68 & -0.05 \\
\hline & 4 & 3.70 & 3.60 & -0.10 \\
\hline & 5 & 3.65 & 3.55 & -0.10 \\
\hline \multirow{5}{*}{ Skin condition } & 1 & 3.75 & 3.83 & 0.08 \\
\hline & 2 & 3.71 & 3.92 & 0.21 \\
\hline & 3 & 3.59 & 3.73 & 0.14 \\
\hline & 4 & 3.60 & 3.70 & 0.10 \\
\hline & 5 & 3.60 & 3.65 & 0.05 \\
\hline
\end{tabular}

イオンガンの加速電圧 $3 \mathrm{kV}$ の条件で刃先のバリを除去で きるが, 刃先は $80^{\circ}$ に形成される. 一方, 刃先側面から照 射すると, 刃先形状の変化を抑えることができる反面, バ リの除去効率が低下寸る.

（2）イオンビームを多方向の角度から連続的に照射すると, バ リの除去とともに刃先角度を極めて小さく形成できる.

(3) 多方向照射によって形成された刃先は, その刃先角度の小 ささゆえに強度が低下し, 切断試験によってナイロン製テ グスを切断することができない.

次に, イオンビームエッチングと後のプラズマ窒化処理によ って, 刃先の鋭角化と耐久性向上を両立させた刃先について検 討を行った結果, 以下の結論を得た.

(4) 多方向照射によるイオンビームエッチング後にプラズマ 窒化処理を行った刃先は, 多方向照射のみの加工に比べ形 状はやや厚くなったが, 従来の皮砥加工よりも刃先角度を 小さく形成でき, $20 \%$ 程度切断性能が向上する.

(5) 多方向照射によるイオンビームエッチング後にプラズマ 窒化処理を行った刃で剔り味評価試験を行った結果, 剃り 味のスムーズさと琵剃り後の肌の状態を問う項目におい て従来品よりも高い評価を得た.

\section{参 考 文 献}

1) 田沜鐵雄 : 実用新案公報,(1956)-3361.

2) 下川房男 : エッチング技術の基礎, 精密工学会誌, 77, 2 (2011) 162.

3) 塚田勉, 鵜飼勝三 : 各種ドライエッチング装置と加工特性, リアクテ イブイオンエッチング装置と加工特性, 精密機械, 51, 7 (1985) 1314.

4) 玉置司, 植村賢介, 岡田晃, 宇野義幸 : プラズマ窒化処理がステンレ ス刃物銅の表面性状に及ぼす影響, 精密工学会誌, 78,1 (2012) 72.

5) 宮本岩男 : リアクティプイオンピームによるダイヤモンドの超精密 加工, 砥粒加工学会誌, 38, 5 (1994) 262.

6) L.Miyamoto : Sharpning diamond knives having a small apex angle of less 
than $55^{\circ}$ with high-energy argon ion beams, Journal of materials science letters, 7, $11(1988) 1175$

7) 玉置司, 岡田晃, 植村临介, 宇野義幸 : イオンビームによるナイフエ ッジのバリ取りと形状制御, 2012 年度精密工学会秋季大会学術亚演
論文集, No.B03 (2012) 99 .

8) 春日幸治: イオンピーム技術の開発, シーエムシー,(2001) 137.

9) 玉置司, 岡田晃, 植村賢介, 宇野義幸 : プラズマ窒化処理がステン レス刃物の切断性能に及ぼす影響, 精密工学会誌, 79, 10 (2013) 950. 